groups, but restricted to purely cultural matters when in contact with the public. In its Third Report for the Session 1947-48, the Select Committee on Estimates, reviewing the work of the British Council, reported that the agreement appeared to be working well and that very little duplication of work in fact occurred. The Select Committee, indeed, saw no justification for abandoning, in favour of the Central Office of Information, the former system whereby the Council was entirely responsible for publishing its own brochures, and deprecated the decision of the Treasury that the Council should buy most of the books it needed through H.M. Stationery Office and not direct from the publishers. Since the Report of the Select Committee was issued, further arrangements have been made to define the scope of the Council's work not only in foreign countries but also in the self-governing countries of the Commonwealth and in the Colonies, and there are agreements with the Central Office of Information and constant liaison to ensure co-operation. Regular consultation also occurs between the Council and the Overseas Service of the B.B.C., because each organization can obviously be of considerable help to the other.

\section{Foods and Fads}

THE subject of nutrition suffers greatly from didactic statements made by people who have no conception of the difference between a point of view and an established fact. Dr. Charles Hill, in his Armstrong Memorial Lecture, delivered before the Royal Society of Arts on December 12, did well, therefore, to belabour some of these amateur 'nutritionists' and expose the emptiness of many of their much-publicized theories. The making of nonsensical statements about the value of various foods is not, however, confined to food faddists and other cranks. Domestic science teachers and even some members of Dr. Hill's own august profession are rank offenders, and Dr. Hill may indeed have had the former in mind when he referred to "the practice of skimming through tables of food values and looking for those foods which show the highest percentage content of certain nutrients ... [and taking no account of] the vital factor-how much of it is taken". Unfortunately, even Dr. Hill himself is not immune. In this lecture, devoted as it is to iconoclasm, some of his own arguments are based on so-called 'evidence' that will not stand up to exam. ination. It is time, for example, that the meat-lovers stopped resuscitating the old unfounded story about the Masai and the Kikuyu. There are also quite a number of statements which no doubt raised a laugh when spoken but which, read in cold print, are now seen to have no bearing on the subject. In fact, Dr. Hill relied far more on oratorical devices than on logical arguments in this lecture-especially in his attack on vegetarianism. His delight in scoring off his opponents frequently made him guilty of just that error of which he was accusing them, namely, the dictatorial assertion of 'facts' for which there is, as yet, no scientific proof one way or the other.

\section{The Bee Research Association}

THE Bee Research Association, which was incorporated in January 1949, has now issued a handbook (obtainable from Dr. Eva Crane, 55 Newland Park, Hull, Yorks, price 6d.) in which all the current and projected activities of the Association are set out. On the research side the Association aims at bridging the gap between the studies carried out in research institutes and their useful application to beekeeping practice. Large-scale co-operative experiments are in progress on the effect of spring stimulation, methods of management of bees, honey density standards and methods of queen introduction. Advice and assistance are given to beekeepers carrying out individual research work on a variety of topics. From January 1 last the Bee Research Association took over the publication of the Bee World. This is appearing in a slightly altered format, and it is hoped, as soon as it is financially possible, to increase its size and to add more illustrations. It will continue to include "Apicultural Abstracts", for which the Association has been responsible since January 1950. In order to tide the journal over its present financially difficult period, a "Bee World Fund" is being created for which donations and interest-free loans are being sought. Full details can be obtained from the Hon. Subscription Secretary, F. E. D. Hodges, 10 Barnett Wood Lane, Ashtead, Surrey.

\section{Lady Tata Memorial Trust Awards}

The Trustees of the Lady Tata Memorial Fund invite applications for grants, scholarships or fellowships for research on diseases of the blood, with special reference to leukæmia, in the academic year beginning on October 1, 1952. Grants of variable amount are made for research expenses or to provide scientific or technical assistants for senior workers. Scholarships are awarded for the personal remunera. tion of workers carrying out approved research under suitable direction; their normal value will be $\mathfrak{f} 600$ for whole-time research. In addition, the Trustees may award one or more Lady Tata Memorial research fellowships to workers with considerable research experience; the stipend of these fellowships would be at the rate of $£ 1,000$ per annum. The awards are open to investigators of any nationality. Forms of application can be obtained from the Secretary of the Scientific Advisory Committee of the Fund, c/o Medical Research Council, 38 Old Queen Street, Westminster, London, S.W.1. Applications must be submitted before March 31.

\section{Conference on Religion and Evolution}

Is response to a request by many teachers, a Conference on "Religion and Evolution" will be held at University College, London, during March 7-8, under the auspices of a number of societies concerned with biology in education. The opening address will be given at 7.30 p.m. on March 7 by the Very Rev. W. R. Matthews, Dean of St. Paul's, who will speak on "Evolution and Theology". On March 8, Dr. L. M. J. Kramer, senior biology master in the City of London School, will give a lecture-demonstration entitled "Alpha and Omega", in which he will deal with some practical relations between religious and biological teaching in schools on the origin of man. There will also be talks on "The History of the Idea of Evolution", by Dr. A. C. Crombie, lecturer in the history and philosophy of science at the University of London. Ample time will be allowed for discussion of the interrelations between religion and evolution and particularly of the practical problems encountered by teachers in the classroom. The fee for the whole conference is $7 s .6 d$., and for single sessions, $2 s .6 d$. Tickets may be obtained from the Secretary, British Social Biology Council, Tavistock House South, Tavistock Square, London, W.C.1. 